Royal United Services Institution. Journal

\title{
The Swiss Military System
}

\author{
Lieut.-Colonel C. Delmé-Radcliffe C.M.G., M.V.O., p.s.C.
}

To cite this article: Lieut.-Colonel C. Delmé-Radcliffe C.M.G., M.V.O., p.s.c. (1907) The Swiss Military System, Royal United Services Institution. Journal, 51:358, 1466-1499, DOI: $\underline{10.1080 / 03071840709418778}$

To link to this article: http://dx.doi.org/10.1080/03071840709418778

曲 Published online: 11 Sep 2009.

Submit your article to this journal $\pi$

Џll Article views: 7

Q View related articles ¿ 


\title{
'THE SWISS MILITARY SYSTEM.
}

\author{
By Lieut.Colonel C, DELAK-RADCLIFFE, C.M.G., M.V.O., p.s.c., \\ British Military Attaché at Rome and Berne.
}

\author{
On Thursday, Tth November, 1907, at 3 p.m. \\ Field-Marshal The Right Hon. The Earl Roserts, H.C.; K.G., otc., \\ in the Chair.
}

THE paper I am about to read is a lecture delivered on September 9th last, at Fribourg in Switzerland, to the members of the British Committee of Inquiry which visited Switzerland for the purpose of seeing the Swiss Army at manouvres and of learning something about the working of the Swiss Military System.

I would ask you to bear this in mind when listening to my paper, especially as the conditions have changed somewhat since the lecture was originally delivered. The most notable change is, of course, that the law for the reorganisation of the military system, which is occasionally referred to in my lecture, has now been accepted by the Swiss people by the voting on "referendum" on November 3rd last. By this vote and by a majority of 62,343 in a poll of 597,558 the Swiss nation has again demonstrated its determination to make continual progress in military efficiency and has given an example of patriotism. to the whole world.

Last year when $I$ was in England I had occasion to discuss the Swiss Military System with: a person of importance. After listening to my description for some time he asked: "Who is responsible for this system? Who designed it?" This struck me at the time as symptomatic, for the answer to this question is, of course, that no one individual is, in any way, the author of the system. No. Secretary of State invented it, as would be almost indispensable under existing conditions in England. No great man arose and persuaded his countrymen that such a system was necessary for them and for their safety. It grew up gradually with the political life of the people of Switzerland-part and parcel of the general social system which regulates their existence. Its origin is to be found in the ancient measures for combined military action which the gallant mountaineers adopted when they first began in small divisions, which were the genesis of the present day cantons, to fight side by side. to keep the enemy from ravaging their homes. Its growth has been gradual, like the growth of the Swiss nation, and its present state is due to the loyalty of the Swiss people to each other and themselves, their indomitable sense of independence, and their fine virility of spirit. It is essentially the opposite of conseription, being founded on the collective free will of the people. Consequently, among the people as a whole there is no complaint of the burther of the Army, of the hardships of the service, of the discomfort and expense. There is the thoroughly healthy and natural view that it is each 
man's duty to protect and uphold the honour of the country of his birth and affections, and each man's duty to be so trained as to be able to render his service in the most effective manner. The keynote of their attitude is, that it is a free man's right and lonour to serve his country, and a disgrace to shirk this honourable duty. Those who are unable to serve owing to physical deficiency are honestly pitied. The few-the very few, who refuse to serve and leave their country are thoroughly despised. It very rarely happens that a man refuses to serve. Cases have been known, however. The usuai punishment awarded by coust martial is three months' imprisonment for the first offence, increasing with each successive training which tlid offender misses.

Although the Swiss are an extraordinarily patriotic people, the authorities and the people themselves recognise the. fact that compulsory service is indispensable, if the military machine is to be made to work satisfactorily.

I was present at two interviews last ycar when an English Member of Parliament asked certain very high officials of State in Switzerland whether such a system as the Swiss Militia system could be maintained on a volunteer basis. The answers were most emphatically in the negative.

When the nation as a whole demands service of its sons it cannot be left to the individuals to decide when or how they will render the service, if at all. The duty of protecting the interests of the Fatherland belongs to each individual in equal degree, and it is considered preposterous that any individuals should shirk this duty and shift it to the shoulders of others, braver, more energetic and more conscientious, and yet continue to participate in all the advantages the service of those others brings to the country. How would the-business of any commercial concern prosper if, one fine morning, it were announced to the clerks that there was no obligation as to doing their work-it was to be left to their consciences to do it or not, as they pleased? Again, in an English public school, if there were no compulsion on the boys to play games, would not all the slackers, just the ones who benefit most by games, loaf about and leave the games entirely to the keen and energetic ones?

Military training, to be effective, especially if the time is short, must be regular, punctual, uniform, and simultaneous. To ensure this there must bo rigid authority.

The Swiss do not hold with the arguments of those who protest that the soldier who has velunteered is alone of any use. They know uncommonly well that proper discipline and manhood will make a man a reliable soldier, whether he volunteered in the first instance or not.

Their own history shows numberless instances of their countrymen fighting magnificently for causes in which they had no interest. English history also. Again, there does not appear to have beer much wrong with the fighting spirit of the crews of Nelson's battleships or of the rank and file of Wellington's battalions. Yet many in both services were anything but volunteers when they joined. Frr a long time past Hunger and Want have been the recruiting sergeants of the British Army. Yet that Army has been known to do some good fighting now and then, although tho number of real genuine free-will enlistments in it can only amount to a small percentage of its strength.

VOL. II. 
Men of spirit will fight as a matter of course. The real obstacle is the ignorance-first and foremost the ignorance-then the indolence and self-indulgence which prevents all classes of a people from presenting themselves in a body for training. It is to overcome this difficulty that wise nations-made wise by experience- have instituted laws obliging the individuals to do their duty. However willing the men of a nation may be to fight when war comes, the vast majority of individuals have not foresight, self-control and methodical habit sufficient to induce them to prepare for war. When war really comes it is much too late to begin.

Modern war between the great nations, through the advances of science and the perfection of communications characteristic of modein civilization, will be waged with every ounce of force brought to play. It is essential therefore that a nation intending to maintain its place in the world must with all its will-power so organise all its man-power and material resources as to be able to make the utmost possible use of all its forces. A nation which fails in this duty to itself gives clear proof that it is in a state of decay and that the inexorable processes of Nature will remove it to make way for others healthier, more vigorous and worthier.

The Swiss nation understands this, and this is the reason why the Swiss Militia Army is, in spite of its smallness compared with the surrounding armies, a far more effective guarantee of the independence of the Confederation than all the treaties ever written.

There is in whe country the conviction that, apart from the probability or possibility of the Army being requirod for the defence of the country, the training to arms and the discipline are morally and physically of the utmost direct advantage to the manhood of their race, and indirectly to the whole people. It is a school for the nation, and, as almost all Swiss in responsible positions will tell you, they say: "If we had not got the Army we should have to invent something to take its place." But the Army must not be regarded as something apart, a separate entity, in Switzerland. It is an intimate factor of the social life of the people, and, in many respects, the backbone of the nation. This is the case to an extent not easy for a stranger to appreciate. To do his military service nppears the most natural and matter-of-course business to a normal man, and all Swiss men, officers and privates alike, seem to take great pleasure in their periodical trainings, which represent healthy outings, with plenty of real hard work in beautiful country with cheery companionship, and the satisfactory sensation of really doing something for the land they love so well.

One advantage of this system, not intended but resulting from it, is that few men marry until they have completed their recruits' courses-that is, till after their 20th year of age. Hence, improvident early marriages, so frequent in England, are very rare here. Again, when it is a question of marriage, it is no recommendation in the eyes of the girls that the man has been registered as unfit for military service. This is an additional reason for regarding such rejection as a stigma.

The accident of geographical position is a cause contributing to the existence of the Swiss military organisation. The military importance of Switzerland in the abstract is very great. Her frontiers are coterminous with those of France, Germany, Austria, and Italy. Each of these Powers would be gravely embarrassed in case of war if the 
enemy could make use of Swiss territory. From Switzerland the road is open down the great valleys of tho Khine, the Rhone, the Danube, and the Po. The lines of defence of each country could in succession be turned from this central position. Though the integrity of Switzerland was guaranteed by the Powers at the Congress of Vienna, and by the Act signed at Paris on 26th November, 1815, Switzerland herself is not of the fibro to accept protection from outside without doing everything possible to render her own defence of her territory effective in itself. She wants no foreign armies, friendly or otherwise, on her soil. Her experience in this sense has been too bitter. She has had too forcible an object lesson of the fate that overtakes a people which, lulled by a long period of peace and a false sense of security, neglects to maintain its proper defences in good order and ready for service. To, refer to this most instructive passage in her history in rather more detail, I may remind you that the practical independence and freedom from attack of Switzerland as regards the German Empire commenced in about 1500. During the 16th century, the Italian enterprises, in which the Swiss fought in the Marignano campaign, against the Venetians, the Papal troops, the Sforza, and the Milanese. This fighting came to an end about 1590. From then till 1798 the Swiss were entirely unmolested. It was during this period that; although not blessed with a Blue-Water School to sap its virility, to tempt it to depend for its security on mechanical appliances and a small number of trained experts, the Swiss people forgot its duty to itself and its country, neglected its training as men and pis.riots, omitted to maintain its organisation as an army, and unwittingly prepared for itself the awful retribution which was to follow, from which it has not, even now, entirely recovered. During this period they lived on the prestige of their fighting ancestors - they foolishly imagined that tho fine qualities their fathers had acquired by blood and sacrifice had descended to them without an effort on their own part. They looked down on all foreigners with supreme contempt, and thought themselves, because unmolested, the terror of their neighbours. They fought among themselves, Catholics against Protestants, groups of cantons and single cantons against each other. But these operations, which one may call of a minor expeditionary character, were no preparation for a collective effort of the whole nation. No doubt, also, they said to themselves: "If the worst comes to the worst, we are sure to muddle through somehow." At the end of this halcyon period they had small cantonal contingents, it is true, and their men were still brave, but they had no organised armies, no. artillery, no staffs, no train, no capable and trained leaders.

The time of sorrow came with the advent of the French Revolution. The French revolutionaries regarded with displeasure the system of Government in Switzerland-the influence and popularity of the old aristocratic families, the prosperity and happiness of the land. They demanded that the Swiss should change all this and revolutionise, too. The Swiss no doubt were astonished that they should be addressed with such temerity-they, the heroes of a thousand fights-fought by their ancestors be it noted-to be thus addressed by the foreigner. They refused, and the French carried out their threat of using force to compel them. Hastily the Swiss called up their scanty and ill-organised contingents. When the shock of battle came the Swiss found that the prestige of their fathers was not

$$
4{ }^{4} 2
$$


enough to defeat the enemy. Infuriated, they tumed on their own leaders and murdered them as traitors, failing to recognise that it was the whole nation which had betrayed itself. Their armies dissolved. They had one or two minor successes, due to the inherent gallantry of the Bernese men, but at Grauholtz finally they were thoroughly. beaten. The struggle continued all over Switzerland with desperate fury. Even women and children took part in the actual fighting, but the Swiss forces were beaten piecemeal everywhere. About 50,000 men and 4,000 women fell in these battles. The slaughter was even continued in the churches, whither the women and children fled for protection. After this the Revolutionary troops robbed the country of everything movable it possessed: money, pictures, plate, jewellery, furniture-everything that could be looted. They simply ate the whole country up-they ravaged and outraged and destroyed and stole, so that rarely in history has so complete a disaster ever overtaken any people.

The French even carried of the able-bodied men as conscripts to fight. The Swiss were forced to maintain a permanent contingent, 15,000 strong, to fight for Napoleon in Spain, Italy, Germany, Austria, and Russia. The Emperor appreciated their fighting capacity, for he left 15,000 Swiss as a rearguard on the Beresina, where, true to their traditions, they fouglit magnificently, between 7,000 and 8,000 being actually killed.

After the French came Austrians, Russians, Italians, and Germans, the country became a veritable cockpit-the invading armies brought typhus and other hideous diseases with them, and, further, so exhausted' the resources of the land that the Swiss themselves starved in thousands. It was not till 1815 that this dreadful state of things came to an end by the Treaty of Paris which guaranteed Swiss integrity. But the Swiss have learnt their lesson, with the result that they are the real nation in arms you see round you today. Their determination now is to make it clear that any violation of their territory, even by the army of the greatest of Powers, would be so difficult, expensive, and dangerous an enterprise that nobody is likely to attempt it. The Swiss people believe that God helps him who helps himself. They have been renowned for their fighting qualities ever since European history became history, even during the period when they so much neglected their own military organisation at home. They fought abroad uncer the flags of many nations and, indeed, of individual employers. Their courage, discipline, and fidelity have been remarkable wherever they served. It is characteristic of their fine soldier-like spirit and bulldog pluck that, no matter how much they may have disapproved of the cause in which they fought when forced to fight as conscriptsonce committed to the fight they appeared to think that their honour as men demanded that thoy shnuld never give way. With this spirit animating them they always fought in a manner worthy of the highest admiration. As a people they thus suffered from their very merits.

The Pope's bodyguard was originally entirely composed of Swiss, and it may interest you to hear that for 300 years, uninterruptedly, it was commanded by ancestors of our friend and guide, Colonel Pfyffer v. Altishofen. How the Swiss guard fought at the Tuileries in 1792 is recorded on the Lion monument at Lucerne. England frequently made use of Swiss legions. In the Peninsular and 
Waterloo Campaigns, for instance, and for the last time during the Crimean War, when two light infantry regiments were formed, called the Britisly-Swiss Legion, under the command of Colonel Dickson. As a rule the men of the Swiss contingents made it a condition of service that they should be commanded by Swiss officers; but they often contentedIy served under British officers. There are many still living in Switzerland who served in Naples, and in other contingents abroad, but of late years the practice has completely ceased.

The constitution of 1848 put an end to conventions between the cantons and foreign, Governments, or rulers, for the supply of contingents, and the Swiss now satisfy their military tastes and instincts with a whole-hearted devotion to their duties as "Wehrmänner" or "Defencemen," as the phrase is, in their own country.

That the Swiss are a people ready to recognise the shortcomings of their system, and are continually endeavouring to remove them, is proved by: the frequent. minor changes in the Army system that have been made from time to time, and by the proposed law for the reorganisation of the Army, which is now awaiting the final vote of the people on "Referendum" on 3rd November, 1907. The Army organisation on its present basis was introduced by the law of 1874. In 1871 the presence of Bourbakis' Army on the frontier, just before it was driven into Swiss territory, caused the swiss to mobilise a part of the Army. 19,000 men were collected, but this operation was attended with so much difficulty, and disclosed so many shortcomings, that public opinion was strongly aroused, with the result that the' law of 1874 was passed which brought about an immense improvement. Since then the Army has been steadily improving, though it is still very far. from perfect or from coming up to the standard desired by the best citizens of the country.

It is an interesting fact that the Swiss were, after the English in olden times, the first people in Europe to adopt the system of universal liability to military service. Tíe Militia system has been in vogue among them for the last 600 years. The three primitive cantons, Uri, Schwyz, and Unterwalden, first started it to defend themselves against Austrian tyranny-Lucerne, Zürich, Berne, and other cantons joined the confederation in succession, but for centuries the Swiss were continually under arms, fighting with outside enemies to preserve their independence, and with each other to settle their domestic quarrels. This, of course, was magnificent training, and explains why the freeborm Swiss soldiers, fighting for liberty in a mountainous country, were so much the superior of the pressed men or ordinary mercenaries of the potentates of the surrounding countries.

From its organisation the Army in Switzerland is entirely a citizen force. In it all classes, all trades, all professions are represented, and the peculiarities, qualities, and capacities of each class, trade, and profession are very much turned to account for the benefit of general efficiency. The doctor and chemist in civil life serve in the Medical Corps; the electrician, engineer, and mechanic in the engineers; the 'bus and cab drivers as artillery drivers; the farmers and horse-owning classes in the cavalry; butchers and bakers in the supply departments, and so on. Thus, for many, the military training is not even an interruption of their usual occupations, for they continue them, not for their own interests, but in pursuit of a greater end. 
The Swiss Army is the most democratic organisation in existence, and is an exact mirror or microcosm of the nation. All have exactly the same obligations, rich and poor alike. No man can become an officer without. first doing his duty as a private and proving further his qualifications for promotion. The only differentiation of any sort is made in the matter of taxes levied in lieu of duty performed. These taxes are imposed on those who, for physical reasons, are unable to serve in person; and in this way contribute towards the defence of their country. The tax varies from $5 \mathrm{~s}$, a year in the case of the poor man, to $£ 120$ in the case of the rich, being determined by a regular scale assessed according to income and means.

The details of how this tax is calculated may interest you. $6 \mathrm{frs}$. or $5 \mathrm{~s}$. is the poll-tax. $1 \mathrm{fr}$. 50 or $1 \mathrm{~s}$. $3 \mathrm{~d}$. is charged for each 1,000 frs. or $£ 40$ of actual property, and for every 100 frs. or $£ 4$ actual income. The income tax is only charged on income exceeding $600 \mathrm{frs}$. or $£ 24$ per annum, and on property exceeding $1,000 \mathrm{frs}$. or $£ 40$. The men of the Landwehr pay half-taxes, and not more than $£ 60$ in all.

Although the Constitution lays down the liability for each Swiss citizen to serve-irrespective of all considerations except physical fitness - a certain number of officials and State employés are considered by the nature of their cmployment to perform services equivalent to military service to the State, and hence are not required to serve with the colours. Members of the Federal Council, some members of the Federal Tribunal, employés of the arsenals, prisons, railways, hospitals, posts, and telegraphs, etc. The duties of these are certainly almost as important in war as those of the fighting troops, and are quite indispensable. Hence, these men are not called out when in the employ of the State.

Swiss living abroad have to pay the tax or perform all the service omitted when they return, if of an age to come undar anyof the categories into which the Army is divided. The non-payment of the tax or the non-performance of the military duty deprives the Swiss citizen of his civic rights.

By Article 8 of tho Constitution, the sole right to declare war, make treaties, etc., is vested in the Confederation. The executive power is exercised by the Federal Military Department. This Department consists of the following offices:-

1st. The Secretariat;

2nd. The Division of the General Staff with five sections and a Secretariat.

3rd. The Divisious for Infantry, Cavalry; and Artillery.

4th. Division for Engineers.

5th. Division for Medical Services.

6th. Division for Veterinary Services.

7th. The Central War-Commissariat.

8th. The Technical Division for war matériel.

9th. The Administrative Division for war matériel.

10th. The Administration of the State explosives factory.

11th. The State horse depôt.

12th. The Division for Ordnance Survey.

13th. The Administrative Offices for the St. Gothard and St. Moritz Fortifications.

In the event of war being declared, the Federal Assembly elects a general for the supreme command, At no other time is there a 
general in the Swiss Army. Officers with the rank of colonel command army corps, divisions, and brigades, carrying out the duties of officers styled generals, lieut.-generals, and major-generals in other Armies. The last Swiss general was General Herzog, who commanded the mobilised Swiss troops in 1871 .

The chief of the Military Department-a function corresponding to that of our Secretary of State for War-is alwass a member of the Federal Council: At the present time it is Federal Councillor Forrer, who last year was President of the Federal Council, while President Miiller was then Chief of the Military Department. Herr Forrer is one of the few Swiss who has no personal experience of military. duty-having been exempted as a young man. He has several times spoken with regret of his lack of personal experience of the Army, and once told me jokingly, that his son, a young officer in the artillery, could do the job much better than he could. But the fact remains that his administration is extremely successful and extremely popular with all ranks in the Axmy. This is worth noting, as it shows that in a country in which the majority of the inhabitants have personal knowledge of military matters, and in which all are directly connected with the Army, a civilian War Minister, with the breadth of view and administrative capacity of the present Chief of the Military Department, can be considered an unqualified success.

The Swiss military system is founded on sound and lasting principles. Hence, no violent changes are necessarv. The conditions change slowly, and with it the organisation undergoes slow processes of ripening and perfecting to bring it into line with modern requirements. A succession of conscientious and hard-working officials is the chief requirement to keep the machinery well oiled and in working order, while the people themselves decide the character which its military organisation shall have, and have to give their sanction before any changes of importance can be carried out. The organisation is complete, and admits of the whole potential force of the country-human and material-being employed. It is now only necessary to work continually at the perfection of the parts, and to carry out such clianges as may be necessary to keep the organisation up-to-date.

The General Staff of the Army includes the General Staff Division at Headquarters, and colonels, lieut.-colonels, and majors on the Army Staffs, and as Chiefs of Staffs of the Army Corps, Divisions, and brigades; also captains serving on all the staffs. A small railway section is formed in the General Staff, and on war breaking out an administrative and executive railway section formed from the personnel of the State railways joins the General Staff. Some details as to the General Staff may interest you. Occasionally, some of the professional offcers of the Army are ordered to join the General Staff, and to command units. But, generally, it is recruited in the following way. The names of about four times the number of captains required as candidates are submitted every year for selection by their superiors. The lists have to pass through the hands of some seven or eight separate authorities for approval. Then the Chief of the General Staff at Army. Headquarters selects some 20 of these officers, after carefully ascertaining their capabilities, for appointment to the General Staff. These officers are then asked if they wish to serve on the General Staff, and if they will guarantee 
to perform the largely increased duties required of them. On accepting, the captain is told off to General Staff courses, lasting 16 weeks in all, and then to perform other Staff duties. The period of first appointment is for four years. "The General Staff officer then rejoins a unit. If all his General Staff service, and service with the unit, is satisfactory, he may be re-appointed to the General Staff, and may even complete his service in it. Formerly, it was contrary to regulations for an officer to remain continuously in the General Staff. The General Staff courses are very good, and besides, General Staff officers have to devote themselves iargely to theoretical study, take part in staff rides, ete: The Federal authorities appoint and promote officers of the Staff and higher units, also the officers immediately at the disposal of the Federal Council, Secretariat officers, the officers of the troops furnished by the Confederation, and the field officers of the rifle battalions.

The cantons exercise the same functions for the officers of troops furnished by the cantons, up to the rank of field officer.

In all branclios of the service officers have to pass through preparatory courses and, courses before promotion-called schools. These courses usually last a few weeks-for appointment to the General Staff the first is 10 weeks, and the second 6 weeks. In all these courses the instruction imparted is of a very high class, and the amount taught in the short time available is astonishing. The extreme care with which all the details of these courses are worked out, and the wonderful manner in which they are rlovetailed into the social life of the country, so as to be as effective as possible, while causing the minimum of inconvenience to the officers-who, in the vast majority of cases, are professional or business men, with affairs of their own to attend to-is characteristic of the perfect genius for organisation which the Swiss people possesses.

It would carry me too far if I were to give you details of theso courses, which can be studied in the publications on the subject. It is sufficient to say that they are carried through in what I may call an "intensive" and serious spirit on the part of instructors and learners alike, and produce results altogether out of proportion to the number of days devoted to the work. Even the Polytechnic Schools contribute instruction, and have special courses for the study of military and military-technical subjects, through which officers desirous of promotion in certajn branches must pass. Proposals are under consideration that the Cantonal Universities should give lectures also on military subjects.

In order to ensure uniformity in the militarv instruction, there is a permanent body of instructors of about 220 officers and noncommissioned officers. These are practically all the permanent troops existing in Switzerland.

The officers of cantonal troops are nominated on the recommendation of the cantonal military directors, and, after passing the qualifying schools, by the "Grosse-Rath," or Council of the Canton. The first promotion is by seniority, but further stages are largely by selection on the recommendation of the military superiors. A Swiss soldier may become a captain after about 360 days' work in the various schools-besides the days required for other courses, such as musketry, manœuvres, etc. Up to the rank of colonel the time is about trebled. The actual amount of time spent in obligatory professional work by the Swiss officer is less than the time a Militia 
officer in England spends at trainings, etc. But the results achieved in Switzerland are certainly much better, owing to the amount of voluntary theoretical study the average Swiss officer gives to his work, the seriousness with which the matter is treated, the completeness in all details of the military organisation, and the actuality, the living reality of everytling. North, south, east, and west, the Swiss soldier-citizen sees other soldiers with whom he can compare himself, and whom he may some day have to fight in defence of his home and belongings.

In addition, there is the great practical reason that the system supplies the men at the right time and place, so that the training can be carried out in the most efficient manner.

A further most iniportant point which contributes in a large mexsure to the eflicacy of the Swiss training is the liberty of manouvie over the country allowed by law, and supported warmly by the public spirit of all the inhabitants.

The Swiss Army is very simply formed into units, as follows:The whole country is divided into eight divisional districts. In each of these the recruiting of infantry for that division is carried out. The recruiting of the special arms is carried out under separate arrangements, in order to get the most suitable men for the various arms requiring special qualifications. The eiglit divisions form four Army Corps. Each division lias two infantry brigades of two regiments of three battalions each. Each division has also a squadron, called a "Company," of Guides Cavalry, one-field artillery regiment of two brigades of three batteries of four Q.F. guns each. Further, a half-battalion of engineers, and a divisonal ficld hospital. The corps troops of an Army Corps include one infantry Landweln brigade, one cavalry brigade of two regiments of three squadrons each, one regiment of field artillery, one corps park, one bridging division, one telegraph company, one corps field hospital, one corps supply section with a supply train. Here, again, I would like to insist upon the completeness of all the units and auxiliary services. The whole organisation is complete, men, horses, vehicles, equipment, etc. On mobilisation everything springs instantly into existence, and every man at once takes the place and performs the duties assigned to lim.

As far as the performance of duty with the colours is concerned, the Army is divided into three categories: the Auszug, the Landwelr, and the Landsturm. The Ausztig includes all men fit for service between the ages of 20 and 32 . The Landwehr includes the men of same category, after they have completed their Auszug service, until they, reach 44 years of age, and the Landsturm includes all capable of serving between the ages of 17 and 50 , who do not belong either to the Auszug or the Landwehr.

The total strength of the military forces of Switzeiland may I-e stated thus in round numbers:- The $\Lambda$ uszug contains 143,000 men; the Landwehr about 91,000 men; and the armed Landsturm, about 45,000 men. The Landsturm is not yet completely organised. This is one of the tasks upon which the military administration is directing its attention. It is partly due to the fact that the law governing the present organisation was only framed in 1874 , that is 33 years ago, and the unarmed Landsturm ranks are only now coming completely under its influence. This is a proof of the length of time it takes for all the parts of a new military organisation to get into working order. 
It is a matter of great importance for us to remember that if in England we were to adopt to-morrow, by a stroke of the pen, a system analogous to that of Switzerland, something like 30 years must pass before the whole great machine would be working. And in 30 years what serious events may not take place. Can we, all this time, rely on the forbearance, or international rivalries, of the continental Powers, or the insularity of our position, gradually getting less and less insular as science devises means for annihilating space -or on the unrivalled diplomatic skill of our beloved sovereign to preserve us in safety?

But to return from this digression.

The armed forces of Switzerland amount, according to the above figures, to about 280,000 men. The unarmed Landsturm is about 260,000 strong. The unarmed Landsturm is used, to a large extent, in the auxiliary services-such as " Pioneers," Medical Corps, drivers" and horses' attendants, guides and carriers in the mountains, signallers, workshop'artificers, storemen and stores workmen, bakers, butchers, oflice assistants and clerks, cyclists, and about 60,000 are described as being "at the disposal of the military commands." There is thus no waste of the human material. As the Swiss population, of Swiss, nationality amounts to about $3,000,000$, it follows that the armed men are in the ratio of about 1 to 11 souls, and the total available number of men who would fight or work for their country in time of war are in the ratio of about 1 to 6 souls of the population. Were our position similar to that of Switzerland, and were our forces in England organised for land defence on a similar basis, we should have in the United Kingdom alone, about four million armed men, and something like eight millions who would be available for military purposes of all kinds. I will not go into details of the various arms in the Swiss Militia, as they can be studied in the published tables, I will merely state that the artillery has altogether 312 Q.F. guns (of which 288 are for the Active Army), 30 Q.F. mountain guns (24 with the Active Army), 54 Maxim guns, about 804.7 guns for field and fortress work, 60 short howitzers of the same calibre, and about 400 older pattern guns in reserve. In England, in the same proportion to population, we should have over 4,000 Q.F. field guns.

The cavalry of the Swiss Army merits a few moments' special consideration. It has been under the influence of a-great organiser, who has refashioned it of late years, and imbued it with a splendid and modern spirit. The men ride capitally, and with lots of dash. The use of the rifle is more fully indulged in than in any other continental cavalry. The scouting and individual work is as good as the training for shock tactics. You will be interested to notice also the use made of the very efficient Maxim companies or batteries, eight Maxims with each, which accompany the cavalry brigades.

The recruiting is special, and the recruits make special application to serve in this arm. They have to produce an official certificate, showing that they have means sufficient to maintain a horse, or a similar certificate as to third persons, who will maintain their horses for them if they are unable to. The recruits have also to come up to a high physical and educational standard. The result is that the cavalry soldier comes of a well-to-do class of the yeoman order, and the esprit de corps in this arm is very high. Families for many generations send their sons into the cavalry, and it is considered a sad misfortune, almost a disgrace, if a young man is not accepted 
for the branch of the service in which the men of his family serve by tradition.

Tho supply of horses is kept up in a most peculiar and efficient manner. Just as the infantry soldier takes his rifle and equipment home with him, and keeps it till he is called out, so the cavalry soldier takes his horse with him. The State shares the ownership in a manner which has been proved to be highly satisfactory. The State buys the remounts at $3 \frac{1}{5}$ years old, and the soldier (also the officer) pays half the cost of the horse to Government, together with the difference between the cost and the auction price, as all the horses are sold by auction to the men. The great majority of the remounts, 98 per cent., are Irish or North German horses, only 2 per cent. are bought in Switzerland. The Irish horses are much preferred, and are being bought in an increasing proportion.

After each year's training-and you will remember that the cavalry in the Auszug $\operatorname{com}_{\Theta}$ out for annual trainings-the Government refunds to the man one-tenth of the original half-cost price of the horse which, at the end of his Auszug service, is on the average 14 years old, and becomes the absolute property of the man. During his 10 years' Auszug service, the man is bound to keep the horse at home, at his own expense, and to join his corps with his animal when called out. The horse must $b_{e}$ well kept, and is periodically inspected by the man's squadron officers, who, for this purpose, visit the men's lomes. If anything is wrong a board is assembled, which decides whether the man or the State is to bear the cost. In this way it is ensured that the man is always well mounted, and the inspection visits of the officers to the men's homes are an additional familiar and pleasant tie between the officers and men in the cavalry. The man can uso the horse in any way he likes, provided that his military readiness and efficiency is in no way impaired. The cost price for troop horses by the time they can be handed over to the men is on the average about $£ 45$ sterling. Thus the State secures the services of a good troop horse for an outlay of about $£ 410$ s. per annum per horse, if the horse fetches no more than his cost price at auction. But they always fetch more, so the State in reality pays less than $£ 4$ per annum. This does not take into account the expense of keeping the young horses six months to acclimatise them, and a further four months for breaking in, nor wastage from sickness and casualties, or other causes. But the total cost to the Swiss Government for each available horse of the cavalry does not exceed $£ 812 \mathrm{~s}$. per annum. In England the cost would be $£ 7$, covering all expenses. The great advantage is, that the State can at all times lay its hand at once on all the horses, trained and in good condition, required for the cavalry. The men are equally satisfied, for they get the services of an excellent horse under the most favourable conditions for their own pockets, that is to say, they are out of pocket only by the amount of the difference between the auction price and the valuation price of the horse-say, $£ 6$ or $£ 7$ on the average. This is a brief and very incomplete summary af the system, but it gives an idea of the principle which seems to me to be as near perfection for yeomanry cavalry as can be imagined. At the present moment the Swiss Government has some 5,300 cavalry horses in the hands of the men on these terms, and another 1,000 in the cavalry depots and schools. In this proportion, and on the scale of the population in England, the Swiss would have about 82,000 
cavalry horses. Of these about 70,000 would be with field troops. A very substantial force of cavalry, I think you will admit. The system, if applied in England, would, besides providing us with an excellent force of cavalry, also be a valuable encouragement to horse breeding in the United Kingdom.

It may interest you to hear that Colonel-Corps-Commandant Wille - who is largely responsible for the excellent present-day condition of the Swiss cavalry-told me a few days ago that this most efficient yeomanry system of the Swiss cavalry was borrowed from Hanover, where it had been introduced when Hanover was English. We may, therefore, claim with some justice, and to tickle our vanity, that its merits are partly English.

I will not enter into details as to the engineer, medical services, commissariat, and supply service, train, railway services, telegraphs and wireless telegraphy, ballooning, arsenals, and establishments, fortifications, etc. I will merely emphasise again that they are complete, existing, and working organisations ready for instant mobilisation. Many of them you will be able to see at work for yourselves.

The permanent fortifications of this country are limited to the defences of the St. Gothard and St. Maurice in the Valais. A small permanent establishment, engaged on civilian contracts, which may be terminated at short notice, is maintained to keep the buildings, guns, etc., in good order and up-to-date, but otherwise they are only occupied, in fact, on mobilisation.

With all these services the key-note is completeness and efficiency.

All the youths in the cotintry, about 29,000 ammully, have to present themselves to the, recruiting officers during their 19 th year. Of these about 52 per cent., or about 15,000 , are accepted ench year for service in the Auszug. The recruiting is carried out by the recruiting staff of each division, so ss to be completed by the middle of October in each year. A plysical and educational examination of each recruit is made. The educational requirements are reading, writing, mental and written arithmetic, geograp'ry, history, and the Constitution. of. Switzerland. Five categories of varying degrees of efficiency in each subject are laid down. This system has a considerable and encouraging effect on the standard of education in the country. A very small percentage of the recruits fail to pass the tests. At the present day, less than one-tenth of 1 per cent. After passing his examination the recruit joins a recruits' school, where in the infantry he puts in 45 very strenuous days' work-in the cavalry 80 , and in the artillery 55 .

It would, however, be quite incorrect to regard the Swiss recruit as a "raw" recruit when he joins, for he lias done generally so much preliminary gymnastics, drill, and shonting during school and carlier years that the recruits' school is really the development of au already very fairly trained recruit. Education in Switzerland is one of the national institutions which has attained the highest degree of development, and it is one in which the people take immense interest. Physical education receives as much attention as mental. The boys are carefully taught the rudiments of drill in accordance with the principles of the military instructions, and also gymnastics. Shooting is the national pastime, to which every young Swiss aspires as soon as he can hold a rifle. In all the country districts wrestling competitions are very popular, and numerously attended. There are, further, the various Cadet Corps in Switzerland. 
The Cadet Corps are worth a few words of explanation. In Switzerland primary education in the State schools, between, roughly, the age of 6 and 12 years, is compulsory in all classes of the population. Children aspiring to higher education pass into the secondary schools. Those that do not go into the secondary schools have, in some towns, to pass a qualifying test about the age of 16, for which they have to prepare in the winter schools, and by going to school for a day or two a week in the summer. But the boys between the ages of 12 and 18 in the secondary scliools, and of the upper middle schools, called "Gymnasium," etc., are those which are the source of supply of the Cadet Corps. A difference of opinion as to the value of these corps still exists, 'with the result that in some cantons or districts, joining the corps is quite voluntary, while in others, as at Wintherthur, which you will see, it is obligatory. In the majority of cases it is voluntary. Up to 16 years of age the cadets get infantry drill, with a short rifle, firing the Govermment ammunition. They fire 30 rounds a year at the target under the conditions laid down in the Regulations. After 16 years of ago the cadets join the Artillery Corps, which is supplied with 6-pounder breech-loading field guns. Each cadet fires two rounds of common shell annually, at about 1,000 yards range. The Communes, or Cadet Commissions, supply all arms, etc., and the Government pays a capitation grant of about $2 \mathrm{~s} .6 \mathrm{~d}$. per cadet. The instructors are the schoolmasters, or officers who voluntarily undertake the duty. A large proportion of non-commissioned officers and officers of the Army are old schoolboys who have served in the Cadet Corps. In 1905 there were close upon 7,000 cadets in Switzerland, and 3,206 fired through their musketry. courses. In the proportion of the English population, the number would be about 98,000 .

But the authorities attach far more importance to the voluntary preparatory military training, through which youths between 16 and 20 years of age may pass. The instruction is given by officers who volunteer to do so during a fow hours a week. The object is "by graduated gymnastic exercises to increase the will-power, strength, and courage of the pupils." . Special attention must be given to the military exercises of marching, overcoming obstacles, and shooting. In the third or last stage instruction is given in drill and musketry. In 1905, 6,132 lads passed through these courses. In proportion to our population, the number would be about 85,000 . The Government draws up the programme for the courses, supplies arms, ammunition, the necessary equipment, pays expenses of various kinds, and encourages them in every way possible. So important are they considered that they will probably be made obligatory before long.

It is frequently asked how it is that with so much physical training the bearing and physique of the average young Swiss is not better. The explanation is, that systematic physical education is of comparatively recent origin in Switzerland. The physique of the people had, as a whole, considerably degenerated through centuries of confinement to their narrow valleys, and too much intermarriage. Switzerland suffered terribly, too, from the period of humiliation through which she passed at the beginning of the last century. Of late years Switzerland has been thrown open by the perfection of the means of communication, and the modern system of education has been adopted by the people in recognition of its necessity. The results achieved in these few years are very remarkable, but it is 
necessary to wait a generation or two to see the full effect of the change in conditions.

Of the shooting in Switzerland, it is not necessary to say much. You, no doubt, all know with what private and public interest the art of rifleshooting is practised in this country. I will merely mention that in 1905 there were 3,694 shooting clubs in existence, with 220,147 members. Of these, 144,344 members fired through the obligatory, and 78,443 through the voluntary practices. The grants to tho shooting clubs amounted to $£ 14,000$. If the shooting clubs in England existed on the same scale, they would contain something like 3,000,000 shooting members, and would draw Government grants of some quarter-of-a-million pounds sterling.

The mobilisation of the Swiss Army is, perhaps, the most rapid there is. As already, stated, each man has his arms and personal equipment-his horse, if a cavalry man-at homo with him. Thase are always maintained in good order and constant readiness. Consequently, when the call is made, which is by proclamation in the case of ordinary courses and manouvres, and by every available means in case of war-the man merely puts on his uniform and knapsack, shoulders his rifle or mounts his horse, says good-bye to his family, and goes straight to his mobilisation centre. Here, when the men are assembled, they fall in, the oath is read out to them, ammunition is issued, and they are ready for the field. No warrants are necessary; the man's uniform is sufficient authority for travelling by train, or any public means of conveyance. The issue of the corps matériel, vehicles and stores from the arsenals takes a little longer, but it is all effected in the minimum of time, as the stores are decentralised, so as to be available where wanted with the least delay. Here, particularly, the Swiss genius for organisation displays itself to advantage. The extreme, almost excessive, care with which all details are arranged is a guarantee that mobilisation can be completed in a wonderfully short space of time. There is little doubt that, if a mobilisation order were issued in the early morning, by the evening all the infantry, cavalry, and engineer units would be ready for the field. The artillery is slowest in mobilising, as it has to take up requisitioned horses. The examination, valuation, and distribution of these takes a little time. By the evening of the third day the whole armed force of the nation would be completely mobilised.

An interesting side-growth of the Swiss Army are the numerous societies or clubs formed to voluntarily practise certain military arts-apart from shooting and gymnastics. They arise from the great desire of the people to do something outside the strict letter of their duty. to further the efficienev of their Army for the good of their country. Such are the officers' and non-commissioned officers' societies with very numerous memberships. In these debates, discussions, and lectures are held-tactical exercises carried out, military studies of all kinds facilitated by libraries, etc.; and even addresses prepared to convey the opinions of the members on matters dealing with the organisation and administration of the Army to the Federal Government. There are, further, cavalry societies, pontooning societies, gun-layers' societies, pigeon-post societies, military musical societies; besides these, the auxiliary societies affiliated to the Red Cross, which instruct personnel according to the Regulations in force, prepare materiel for store, for transport and hospital uses. Annual grants to the extent of $£ 1,000$ are allotted for work in this field 
in the direction of ambulatory lecturing, technical publications, and so on. The Central Association of the Red Cross has 30 branches, with 15,330 members. The Swiss Military Medical Society has 24 branches, with 550 working members; the Society of Good Samaritans has 163 branches, with 7,111 active members. On the scale of the population of Fngland these societies would number together about 400,000 members.

I have heard the argument used that the introduction of a system of compulsory service in England would kill all volunteering and the voluntary spirit. If the Swiss nation is any guide, it would scem difficult to make a more incorrect statement. Apart from the voluntary organisations just referred to, and the Cadet Corps, and the voluntary preparatory military training referred to earlier, it must be remembered that all the work performed by officers and non-commissioned officers may be called voluntary.

Para. 76 of the old law, and para. 10 of the new law, lay down the principle that a man must accept promotion, and the duties it carries with it. It is only in rare instances in the infantry that the law has to be relied on to induce men to go tinrough the non-commissioned officers' courses. There is never any difficulty in getting them to accept the rank and duties afterwards. The officers require no persuasion at any time, and the number of officers serving is largely in excess of establishment. In a general sense, it is very much preferred not to make a man serve as officer or non-commissioned officer who does not wish to do so.

The number of officers and non-commissioned officers in the Swiss armed force is such that, in the proportion of the English population, it would represent more than 500,000 men, or as many as our Regulars, Militia, and Volunteers in England put together. It seems, therefore, that there is not much in the argument that compulsory military service would kill the volunteering spirit. On the contrary, my conviction is, that it would encourage it very much, as men lhaving passed through their recruits' training, know their work and know that everything they are willing to do is taken real and full advantage of for the benefit of the country. The right sort of man has a liking for genuine soldiering, a liking which is, after all, inherent in human nature, and develops with encouragement. The sort of keenness that animates all ranks in the Swiss Army very much resembles what one sees in one of our crack volunteer regiments, or of a good company of Regular infantry going through its company training under a capable captain. Indeed, the whole training of the Swiss Army resembles the concentrated and invaluable instruction given in our service during the annual company trainings. Most officers will admit that 75 per cent. of the useful teaching - the real effective training - which our men get is given during the company trainings and in the musketry courses.

The Budget of the Swiss Army is naturally of the greatest interest. In each year's Estimates, under the heading "Military Department," appear the accounts relating to the Army. But these do not represent all the military expenditure, for under headings such as "Government Investments," "Department of the Interior," "Finance and Customs' Departments," etc., apprar items which aro strictly military. In order to know the true military expenditure it is necessary to place all these items together, after extracting them from the various leadings under which they appear. Under the heading of, "Receipts" appear a number of items, such as the 
proceeds of the tax in lieu of performance of military service, of which half goes to the Cantons and half to the Federal Government. Also proceeds of sale of old weapons, etc. The tax in lieu of inilitary service brought into the Federal and Cantonal Governments last year the sum of $£ 166,000$.

On the whole, the Estimates show a regular and steady rise, though this rise is only in proportion with the general rise of prosperity of the country. I have made careful extracts from the Estimates of 1907, which I believe cover all military expenditure, with the result

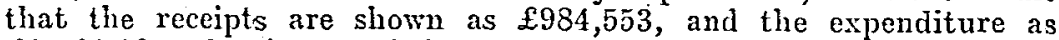
$£ 2,366,885$, leaving a balance of expenditure over receipts of $£ 1,482,341$, or nearly $1 \frac{1}{2}$ millions sterling. If the population of Switzerland equalled that of England, the Army organised on the Swiss system would cost about $19 \frac{1}{2}$ millions sterling, and this sum would also cover the auxiliary services of another $4,000,000$, who would set the armed 4,000,000 free to appear in full strength in the field. The expenditure may be stated in another way. Each armed Swiss defence man represents an anuual outlay of about $\mathfrak{L j}_{\mathrm{O}} \mathrm{G}$. The unarmed and armed human war material together represent an outlay of about $£ 215 \mathrm{~s}$. per head per annum. It may be objected that the conditions in England and Switzerland are different. So they are, but largely to England's advantage in the matter of economy-our industrial resources are incomparably greater. We could pay officers and men more, possibly double as much as in Switzerland, and this would balance the economy in the production of matériel, food supply, horses, etc., so that the net expenditure might be in the same proportion after all.

You must remember that in England we should only bave about 130,000 men annually available for a Nilitia Army, after the needs of the Navy, the Regular Army, and of the Mercantile Marine have been satisfied, and after allowing for emigration, and the necessary rejections on physical grounds.

The principle of universal obligation to sirve should be equally applied to the men of the Mercantile Marine in relation to the Navy instead of the Army. A great reserve could thus be created for the personnel of the fleet.

All are agreed that the recruiting for the Navy cannot be encroached upon, but it is not clear that all recognise the equally imperative needs of the Regular Army, which alone can enable us to fulfil our Imperial obligations. Circumstances might arise which might conceivably require us to reinforce the garrison in India with $50,000 \mathrm{men}$, or more, to stay there some time. This must be a function of the Regular Army. Complications may also arise in other parts of the world requiring the immediate employment of a striking force of from 100,000 to 150,000 men. These must also be furnished by the Regular Army. The National Militia Army cannot replace the Regular Army. But it would immensely increase the effectiveness of the Regular Army, as it would of the fleet, by setting them both free to carry out in full strength the duties for which they exist.

Therefore, the 35,000 recruits anmually required to keep the Regular Army up to strength must not be encroached upon. But with a recruit contingent of 130,000 men annually, giving them a three months' recruit course and eight annual trainings of a fortnight afterwards, we should have an Army a million strong, costing

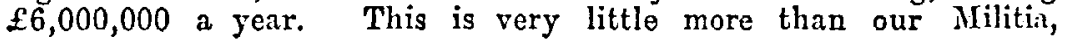


Yeomanry, and Volunteers cost, probably less, if all the expenses incurred on behalf of the Auxiliary Forces could be ascertained, while it would be infinitely more efficient as an Army.

People sometimes say we could not possibly want such an Army in England, but it must be remembered that an Army on this Militia footing is not a Standing Army. It is an Army which never appears except in fractions for training, and in full strength only to meet the enemy. Thousands of visitors to Switzerland every year never see a soldier, and apparently think a Swiss regiment must be as rare an object as a Swiss battle-ship. The large-and to the anti-militarist, shocking-figures of the strength of a National Militia Army, represent the Army in posse-what it would be if required to fight. You cannot, then, have too many. At all other times the Army in esse is only in existence during the few days of its training. In Switzerland at no time does the number of men under arms exceed one-fifth of the total strength, and this number is only reached during the most strenuous period of the autumn manoeuvres. It is an Army which, in peace-time, never is an Army. It has no barracks to speak of, and gives little evidence of its existence except during trainings. On an enemy's threat, however, it at once becomes a mighty and complete Army-a host stamped from the ground, armed from head to foot, and ready for any eventuality.

I will state the effect on the country of universal service on the Swiss model in another way.

The whole Swiss Army represents in days of work during the year roughly, the output of 6,000 men of a permanent force. The $4,000,000 \mathrm{men}$, proportionate to a population of $40,000,000$, would correspond to a Standing Army of about 82,000 men. This is only about one-third of the strength of our Regular Army, without taking any of the Auxiliary Forces into account at all. A Militia Army of a million men would, of course, correspond to a permanent force of about 20,000 men. This does not seem a figure sufficiently formidable to inspire even the most rabid anti-militarist with horror.

The total amount of energy diverted from trade or business is obviously very much less than is the case with a Standing Army of the usual continental type.

The question of the pay of the Swiss soldier may be touched upon. Nobody, of course, gets anything when not actually serving, and there are no pensions except to individuals (or the families of individuals), who may die or become invalided in or througu military duty. The private of infantry receives $8 d$. a day when on duty-a cavalry trooper 10d. a day. The highest officers in the Army get up to as much as $£ 2$ a day. when on duty, and certain travelling and horse allowances. The only individuals who receive a fixed yearly rate of pay are the heads of departments and military establishments, and their staffs; also officers and non-commissioned officers of the instruction personnel. The pay of the Chief of the Military Department is $£ 480$ per annum. Chief iustructors of arms, that is to say of the infantry, cavalry; artillery, etc., get from $£ 220$ to $£ 240$ per annum, and about $£ 48$ horse allowance. When on duty officers and men are entitled to rations daily or $10 \mathrm{~d}$. in lieu.

The administration of the Army is a littie difficult to understand at first, owing to the double sovereignty of the Confederation and the Cantons. It does, in effect, lead to some friction and loss of efficiency, but the Cantons are so jealous of their rights and

vOL. II.

$4 \mathrm{w}$ 
privileges that it is a slow business overcoming this obstacle. But still, education, and a liberal spirit are at work calming susceptibilities, and showing the way in which the best efficiencr can be attained for the benefit of all. Attempts have been made from time to timo to curtail the influence of the Cantons, and increase that of the Federal Authorities. Progress has been made, and will, in future, be greater. The ideal sought is just that degree of decentralisation which admits of the most effective administration, while, at the same time, leaving the Federal authorities absolute powers of executive and direction.

All the Cantons have State Councils and Councillors, In all general matters of administration they are independent. They have machinery of their own for the execution of the Felleral laws. This system extends to everything. There are, therefore, in Switzerland, 25 different forms for the application of laws, and 25 penal codesthe penal law being still within the competence of the Cantons, while the civil code is almost entirely Federal now. It is in process of change, and will soon be quite Federal.

The State Councils of the Cantons have each, in due form, a Military Department or little War Office, under a military director. Within the competence of the military directory come the following functions :-

1. The providing of the troops for the infantry, 32 rifle companies, the Dragoon squadrons of cavalry, 48 batteries of field artillery, and 10 companies of position artillery, also the appointment of officers of the Cantonal units up to the rank of major, though no officer can be appointed without the certificates of qualification issued by the Federal autliorities.

2. The providing of the whole equipment for the men, except arms, for which repayment in money is made by the Federal Government, which also supplies all arms and corps matériel direct.

3. The Cantons are responsible for storage and maintenance of the whole of the arms, ammunition, clothing, and equipment of their troops.

4. The Cantons have to supply the eight territorial divisions of the Army, partly at the expense of the Confederation, with sufficient divisional artillery and infantry ranges, field fring areas, and also with barracks, which they must maintain. For the expenditure on these items the Government now reimburses the Cantons to the extent of 5 per cent. annually on the capital sunk in buildings, and 4 per cent. on land. Profits from lands belong to the Cantons, which in this way recover some of the outlay. The right of expropriation exists for land required solely for military or public purposes; speculation is guarded against by the rule that land no longer required for military purposes must be at once returned to its original owners.

5. Tho superintendence of all movements of men of the Cantonal units within the Cantons is Cantonal business. This function is the one which occasions the heaviest amount of work to the Cantonal authorities. Further, the collection of the tax in lieu of personal service is Cantonal business; half of the tax is retained by the Canton, the remainder being remitted to the Federal Government.

6. The granting of leave of absence from duty in the Cantonal units is a Cantonal function. Men are sometimes excused from training when the training takes place at a time which might cause a man 
very serious loss in his business, or they may be excused for sickness or on account of sickness or death in the family. For those thus excused, "Nachdienstkursen" or "casuals" courses are arranged. These "casuals". are formed into separate provisional battalions, or other units, in each division, and carry out complete repetition courses of their own. In case of officers the Chief of the Arm at Headquarters is consulted. Exceptional circumstances are taken into account when granting leave, and the decision rests with the military director. This has given rise to some dissatisfaction, and it is felt that the officers commanding the troops should have more to say in the matter.

The superintendence of the compulsory shooting courses is Federal business.

Practically, all other military business is Federal. The recruiting is carried out under Federal district recruiting officers, with the assistance of the district commandants. Several districts are united under each divisional commandant. The district commandants are appointed by the Cantóns; 15 to 20 communes, according to size, under soction-chiefs, are united into districts. All expenses on account of Federal functions are paid by the Federal Government to the Cantions.

The examination of recruits, their distribution to the various arms, their instruction, the administration of the Federal troops and special troops, armament, workshops, the supply of corps materiel, the appointment of the higher staffs, and of all officers above the rank of major, is all Federal business. Company non-commissioned officers are appointed by their company commanders; battalion non-commissioned officers by the majors. For the Army Staffs and General Staff, non-commissioned officers are appointed by Federal authorities.

The Staff of the military directors of the Cantons consists of a secretary, the superintendents of arsenals and stores, with a staff of workmen and a body of clerks.

The remainder of the field artillery, and of the position artillery companies, the guides cavalry squadrons, the Maxim companies, the rifle battalions, the engineers, the mountain. artillery, the ballon company, the medical supply and adminstrative troops, are all Federal. The now law proposes to make the whole of the field artillery Federal at once.

The chief arguments now used against the centralisation of authority are; that it would be making the army a Standing Army, that the sovereignty of the Cantons must not be interfered with, and that the expense would be increased. The first and last arguments have no foundation at all. The matter of the sovereignty of the Cantons is really the stumbling-block, though it is a sentimental one. The dual sovereignty and administration is the reason why, as at the Beundenfeld at Bern, you will see stores and establishments, of both the Canton and the Federal Government, side by side. On the other hand the Cantonal system facilitates decentralisation, and leads to a good deal of healthy rivalry and esprit de corps. The men of Bern and of Fribourg have no great admiration for each other, but they strain every nerve to outdo each other in military excellence.

Although the pay of the Swiss soldier is small, the State makes provision for the families of such men as have met with serious mishap in, or as a result of, their services, and are consequently prevented from supporting their families altogether or in part. This 
relicf is only given, however, to the poor, who really require it. $A$ certain'amount of provision is also made by the Communes for the indigent families of men called to the Colours, and which would be left otherwise in distress. It is proposed, by the new law, to extend the scope of this relief a good deal, so that the really poor may not be sufferers, owing to the breadwinner of the family being called away in his country's service.

The extent to which trade and employment are interfered with by the periodical calls for trainings, secms to be really slight. In ordinary trades and business, or professional occupations, the disturbance is very slight. The actual periods of duty are known to all beforehand, and the disappearance of the individual from his work for a time is perfectly a matter of course. The doctor or solicitor puts a notice into the paper to say that he will be absent at manœuvres. The hotel porter gets so much leave from his employer. The individual who suffers most is the farmer, who may have a crop to get in just at the moment when his farm hands are called away to the Colours. I met near Bern the other day a farmer who was looking at his ripening crops. Talking to him about the mancuvres, he said that all his five sons had been called out at the same time. I asked him what they were employed at, and he said they all worked on his farm. On my saying that he would have some difficulty with his crops, he said: "Yes, but we'll try to get them in first, and what we can't get in then we'll get in after." He was quite philosophical about the matter, and showed no sign of considering it a hardship that all his sons had to leave at a critical moment. The staunchest supporters of the military system are the farming class-the bulk of, and the best of, the population. They have the most to lose by it, but they recognise its value, and accept the inconvenience for the sake of what they know to be the general good. The loudest outery against the system is made by just those classes who lose nothing and are not even inconvenienced by their short periodical spells of duties, and who are precisely the people who benefit most by being subjected to discipline and wholesome physical and mental training. It is this class which supplies the few antimilitarists who spread fantastic tales about the Army being used to oppress labour, of shooting down unarmed crowds, of bayonet charges against women and children. These are all shameless inventions, for no shot has ever been fired, no bayonet charge has ever been delivered, and nobody has ever been killed by the troops. A few slight injuries only have been inflicted. Soldiers have only been called out to suppress disorder and ensure respect for the laws of the land.

It is the few anti-militarists, too, who lead the clamour against the employment of the military in case of riots. Owing to the military system, every: Swiss man becomes, in a sense, the guardian of the good order of the country. This sense of responsibility of the citizen is the reason why Switzerland requires so small a body of police. In a town like Lucerne, for instance, there are only 40 policemen, or 80 when the tourists come. If the National Army were not there to uphold the law of the land, the police force would havo to be largely increased. What the people in this country think of riots, disorders, and their suppression may be inferred from the facts of the strike riot at Ziirich in 1906. The anthorities hesitated so long in applying force to quell the disturbances 
that the inhabitants of the communes, which were the scene of the troubles, lost all patience, and threatened that unless the Government would call ont the troops and restore quiet, they themselves would turn out with their bayonets and drive the rioters away. This attitude of the people was one of the causes which finally induced the authorities to turn out the troops for the unpleasant duty of suppressing rioting. When the troops were turned out, and this was done with great rapidity when finally decided upon, the trouble ceased as if by magic, without a slot being fired or a bayonet being used. The truth, however, is not always a safeguard against the malicious statement of the anti-militarist fanatics, and calculating professional demagogues, who endeavour to represent the troops as being employed against labour (a preposterous statement, since labour is the source of the country's prosperity), instead of against disorder, as was really the case.

The disturbance to trade, to the business of the great industrial establishments, and to the earnings of workmen, may be estimated by the figures placed at your disposal by Messrs. Sulzer Brothers, of Wintherthur-the chiefs of one of the greatest industrial concerns in the country. Of their 3,454 workmen of Swiss nationality, $28 \cdot 4$ per cent. are liable for military duty-that is, to service in the Auszug, men between 20 and 32, and in the Landwehr, men between 32 and 44 years of age. There are, of course, many men in the works who have not been accepted for military duty, or who are beyond the liability age. In $1906,16.6$ per cent. of the workmen performed military duty, but only about 21 per cent: went through the, longer recruits' course. The loss to the firm was altogether 144 per cent. of the total working days in the year.

Employers of labour in Switzerland consider that the small loss in working time is more than compensated for by the increased efficiency of the men.

I now come to a partion of my remarks which, I confess, cause me a little difficulty. It is the critical part. You may think that I have been so unsparing in my praise of all things connected with the Swiss military system that I have left no room for criticism. You will say that in all organisations there must be some parts less perfect than others. There are some points in which the weakness of a Militia syptem is evident. I am the more emboldened to speak out on this subject, as the best Swiss officers know the weak points as well as any outsider can, and have criticised them quite unhesitatingly. It is part of the splendid spirit of this fine Army that they do not attempt to gloss over their failings, but drag them into the light and continually work for improvement.

One weak point of the Militia system is the misfortune that political " pull " sometimes enables men of less capacity to oust others of greater capacity from important appointments and commands.

In Switzerland there is very little of this, for public life is very sound and pure. Besides, officers in prominent positions are so watched and criticised by an intelligent and appreciative public, that men of a dangerous degree of incapacity cannot long maintain their positions, any more than it would be easy for a third-rate cricketer to hide his incapacity if made to play in an all-England eleven. The danger exists though, of men, not quite the best, being appointed to positions they should not occupy, and this danger the Swiss recognise themselves. 
I think it is usually admitted that the weakest point in their Militia system is the difticulty of procuring officers and non-commissioned ofticers having sufficient practical and theoretical knowledge. Nothing whatever can be said in disparagement of these cadres from the point of view of ordinary education or keemness and devotion to duty. Their keenness is really quite admirable, and what they do learn in the short time they have to study the many-sided and difficult business of an officer's duty, is simply astonishing. But good-will and good material are not sufficient alone to turn out the highly: qualified officer. He must also have years of experience, of study of the theory and practice of the profession, and, especially, he requires much practice in the handling of men. Otherwise, lis cannot be so much superior in professional knowledge to his men as to have that ascendency over them which is indispensable if he is to get the best value out of them. There are many officers in the Swiss Army who would bo an ornament to any Army-men who are brave soldiers and leaders, and who have also in their own time, through sheer passion-for soldiering, studied and learnt as much as offeers of their rank in any standing army. Every officer must also have been through the whole mill. No man can become an officer without satisfactorily performing his duty as a private, and further satisfying the rigid demands of the higher standard of an officer's qualifications. The fact is, that the profession of an officer requires more time and work than a man engaged in the ordinary pursuits of civil life can give to it. We are here confronted by the almost unsurmountable difficulty presented by the Militia system. The proportion of professional officers is a difficult matter to decide -it is important to train the Militia officer to command; therefore the commands cannot all be held by professional officers. But the purely instructional duty has a narrowing effect-rather tending to routine habits of mind. I certainly think that we should require the proportion of professional, permanent, officers to be higher than it is at present in the Swiss Army. The Achilles heel of a Militia Army lies in the difficulty of providing officers and non-commissioned officers with sufficient practical professional knowledge and experience in leadership and command. The small body of instructors-permanent officers-in the Swiss Army renders priceless services, and one has only to observe the handling of a detachment by one of these to recognise the touch of the expert. The organisation of the Swiss Army has been thought out by. highly-competent experts, and the training of the troops is almost entirely due to the small body of professionals. Under the easy conditions of peace mancuvres, the shortcomings of the subordinate leaders are noticeable. Under the infinitely more trying conditions of war, the weakness might have serious conseruences. What the most competent critics in Switzerland think may be gathered from the frequent reports on the subject. We should be better situated in this respect in England. Prominent Swiss officers have often said to me: "What an immense advantage England would always have in her permanent Army-if she crganises an Army like ours for home defence. She can always have the services of a large number of highly-trained staff and regimental. officers. The Regular Army would supply just the element we lack."

Another point of less excellence in the Swiss Army is the artillery. The material is good-the batteries are well turned out and well organised, and the men are excellent, so far as hard work and good- 
will are concerned. The horsing of the batteries, considering that it is all by requisition, on payment of $5 \mathrm{~s}$. $10 \mathrm{~d}$. per day per horse, is very good, too. But the employment of the arm is a little behind the times. I think, on the whole, as artillery, it is a little lesa efficient than the other arms of the Swiss Army are, each of their kind. The causes for this may lie in the nature of the arm, and the difficulty of training in a Militia Army. You can teach an infantryman much of his work in private life, and at odd times-to shoot, to march, to drill even, to look after his uniform, his weapons and himself, and so on. You can teach a cavalryman to ride and. shoot, and a man with the natural aptitudes and goodwill becomes a creditable trooper-as we see here-in a very short time. A civil engineer becomes a good military engineer, almost with the change of his clothing. But in private life you cannot drag field guns about the streets, practise with shrapnel in the back garden, gallop about the country with teams of horses and guns, and practise all the complicated and technical business of ranging, indirect fire, the use of goniometric sights, massed and isolated action of batteries, slow, rapid, and rafale firing, etc., to say nothing about horsemanship, riding, driving, etc. Without great skill in these matters the gunner nowadays is hopelessly at a disadvantage. It seems very difficult to train artillery sufficiently in the short space of time the Swiss Army has for training. If the Swiss cannot, I think we may take it that nobody can. Yet the ordinary drill of the Swiss artillery is good. They get plenty of practice, too, for in each repetition course, each gun fires some 180 rounds of shell.

Since I wrote the above I have been discussing the point with one of the most eminent officers of the Swiss Army. He told me that the difficulty of the artillery was not due to an inherent defect of the Militia system, so much as to a traditional formalism handed down in the artillery from former days.

If the Swiss artillery as artillery can be made as efficient as the Swiss cavalry is as cavalry, we may say that the Militia system will answer for artillery also. There are many capable men working hard to raise the general efficiency of the artillery. As this persevering people generaily succeed in removing what it considers to be defects, there is no doubt a hopeful future for the artillery.

These are, gentlemen, in my humble opinion, the important points in which the Swiss Army is less excellent than elsewhere.

You have, no doubt, heard a good deal about the new law for the reorganisation of the Army, which is to be voted upon on Referendum by tho poople of Switzerland on 3rd November next. I will give you a brief résumé of its chief features. They are:-

1. Full provision for the family of a "Defence-man," which is placed in need through the man being called to duty. This provision cannot ever be reclaimed by the State, and is, therefore, not a loan or a debt of the soldier's. This will remove almost the only cause of any hardship to individuals through the military service. Its need has been increasingly. felt of recent years, and its introduction is a great satisfaction.

2. The furnishing of a proportion of the troops with mountain equipment. It may seem odd to you, that though Switzerland is par excellence the mountain country of Europe, a very large proportion of the Army is not equipped as mountain troops. I confess that 
it is inexplicable to me. Troops equipped for work in the mountains are always at home in the plains, but the converse does not hold good. The French, Italians, and Austrians, too, have now large bodies of troops specially equipped and trained for work in the mountains. The Swiss are at last about to make good what many of their best officers consider a serious defect.

3. A much more cirtensive support by Government of the Gymnastic Associations, which will now officially be charged. with the physical preparation of the youth of Switzerland for their duty as citizen-soldiers. This is another good step forward in the matter of the physical education of the people.

4. Increase of the period of the recruits' courses, from 45 to 65 days for the infantry, from 57 to 75 days for the artillery, and from 82 to 90 days for the cavalry. In this we see the recognition of the truth-that 45 days is no longer sufficient for the training of the infantry recruit. Modern fighting makes such large demands on the individual intelligence and skill of the soldier in the ranks, that it is absolutely indispensable that he should receive a higher degree of individual training.

5. The repetition courses for the infantry and engineers in future to be annual ones of 11 days each, instead of biennial ones of 18 days. The artillery and fortress troops will have annual trainings of 15 days. It is felt that in this way the men will be kept more up to the mark, and the excellent results achieved in the cavalry, owing in part to the system obtaining in that arm, give good grounds for the opinion that similar benefits will be derived by the other arms. The number of repetition courses, too, will be seven, and, falling in the earlier years of a man's service, will thus cause even less disturbance to his civil occupation than now.

6. The period of training for junior officers, especially of the infantry, is to be increased to 220 days instead of 200 . The great necessity for improving the training of the officers is recognised in this measure. Also for officers above the rank of captain the periods of training for the General Staff are to be increased.

7. A certain increase of the executive functions of the Central Authority, and a corresponding reduction of the functions of the Cantons, is proposed. This is necessary for the increase of efficiency in various branches of the service. It is also proposed to make tho whole of the field artillery Federal troops, instead of being, as now, 24 batteries Federal and 48 batteries Cantonal.

8. Increase of the direct influence of the higher leaders on the recruiting, training, and command of the troops serving under them. This is an excellent measure, designed to increase the efficiency of the commanders by increasing their responsibility.

The additional work demanded of the men is only a total of 10 days, spread over all their Auszug service, and against this 7 days formerly devoted to inspection of arms during the years the men are not required to turn out can be deducted.

The additional charge on the estimates will be only about $£ 200,000$ a year. This can easily bo covered by the surplus of the revenue.

It will thus be seen that the proposed law for the reorganisation for the Army contains nothing but very moderate and thoroughly wellthought-out measures for increasing the efficiency of the Army in just those points in which it is known to be lacking. This law will bo submitted to the vote of the people on 3rd November next, and 
it is hoped that improvements so desirable, decided on practically by the unanimity of both the Cliambers, will also meet with tho approbation of the sensible and patriotic portion of the people. When the signatures were obtained for claims for the proposed law to be submitted to the "Referendum," it was found that some 88,000 votes had been registered for the application of the Referendum. It remains to be seen if this number will be largely increased in favour of rejecting the proposed law. The total.number of voters in Switzerland is 809,000 .

The troops that you will see at this year's manouvres aro the 1st Army-Corps and a manouvre division, formed chiefly from troops of the 2nd Corps. This latter has almost the strength of an ArmyCorps, as it contains 19 battalions of infantry. As an experiment, it has been formed as a Grand Divislon on the Japanese model with three brigades: This is interesting to us, as it resembles the big division adopted in our Army. The infantry of the lst Army Corps consists of French-speaking troops. In the Mancuvre Division the infantry is chiefly from the German-speaking Cantons.

You will see many. things of great interest in these manœuvres. Perliaps you will allow me to direct your attention to the accurate and quiet manner in which you will see a whole Army Corps with a front of sereral miles directer on to the line which it will be required to attack. There may be changes of direction and changes of plansperhaps taking place at night-but in every case the general accuracy of movement will be maintained without hurry or fuss, and conclusive proof will thus be given of the efficiency of the commands. and staffs. You should particularly notice the admirable march discipline of all bodies of troops and trains. Everything marches quietly, steadily, well closed up. You will see infantry marching, perhaps after doing 25 miles with little or no sleep the night before, a tiring fight during the day, and carrying 66 lbs. weight on their backs, but still as.steady and well closed up on the march, and as willing if called upon for a fresh duty, to entrench or whatever it may be, as if they had iust turned out. Real good infantry it is. Pay special attention to their fire discipline, for you will see none better in any army in the world. Watch the cavalry-smart, intelligent, quick, well mounted, equally good in isolated as in mass action-and you may well marvel how such can be created in 80 days to begin with, and less than a fortnight once a year after. Look at the artillerygood and complete at all points, in movement and drill, and think what good conmanders could do with such material. Look carefully at the train columns in the road-the discipline there, difficult as it sometimes is to maintain in such columns, is perfect. Remember that all the troops out, about 52,000 men, are fed, as in war, by the supply services-not by local requisition. Hence, the conditions closely resemble war in this respect. There is greater freedom for the commanders as lo manouvres, as they are not tied to certain billeting areas. That the troops have not more often to wait for their supplies, speaks volumes for the efficiency of the Commissariat. Note, too, the rapidity and completeness with which each unit shakes down into its cantonment area when halted. This is due to the fact that the communal authorities have permanent lists of the available accommodation in barns, stables, etc. The troops are not billeted into houses at all. The allotting of the troops to their so-called cantonments can thus be carried out with extreme rapidity. The only 
housing supplied for the men are reading rooms, where the men can write letters, read the papers, and so on. Usually some villago school-room or other public room is used for this purpose.

Pay close attention to the big review on the 12 th September. You will see that there is nothing whatever prepared for show in the Swiss Army-uniforms, etc., are all of the simplest descriptions; but the impression made by the whole is, perhaps, all the more deep. Remember that the fine review you will see, in which the troops will be displayed in first-rate style, is not a thing which has been reliearsed. None of the units you will see have marcned past before, except on a similar occasion two years ago. Under these conditions, so good a parade could only bo possible through first-rate staft work, excellent organisation; and the best efforts of everyone concerned. If tho review were better or more spectacular, it would be proof that too much time had been wasted on an unimportant exercise. That tho result is as good as you will see it to be is simply astonishing, and really must be seen to be believed.

The points of chief excellence in the Swiss Army, after the spirit which animates it, and which must always be placed first, is the perfection of the organisation in all its details, down to the smallest of the subsidiary services. It really is an Army, complete and ready. Remember its readiness for instant mobilisation, and compare it with what you have known our own to have been hitherto in these respects. Remember that this truly great little people has created for itself this excellent Army, which, with a population as large as ours, would correspond to $4,000,000 \mathrm{men}$, with 4,000 field guns and 70,000 cavalry, costing $19 \frac{1}{2}$ millions annually, entirely of itself and by itself.

In conclusion, I would beg you, above all things, in studying what will be shown you of the Swiss Army, to direct your attention mainly to the splendid spirit of the people and of the troops under arms-remember that in this country Almy and people are one and the same thing. Remember that it is the people that creates the army, and that if in England we are ever to have an army wortly: of our place in the world, and equal to modern requirements, that that army must be created by the people too.

The men in England who can direct the people's attention to this vitally important question will have rendered their country immense and lasting service. It is really the most important question of our time. It cannot be doubted that a people, with the commonsense of our people and the patriotism, which we believe underlies their apparent indifference, will appreciate the points when it has studied the matter, or that it will insist that the best measures be adopted to ensure the security of our Empire, the well-being of our race, and the peace of the world. Once the people of England have become familiar with a system like the present Swiss Militia system, have learnt that the devil is not so black as he is painted-that the expressions "militarism" and "conscription" are phrases without meaning when applied to a national service system like the Swiss, and that such a system is of the greatest benefit to a people, and has no drawbacks, then all the great body of hard-working, sensible, patriotic Englishmen will surely insist that we have it. But they must first thoroughly understand what it all means. And it must be your business, who will have seen things for yourselves, and particularly of the gentlemen representing the Labour party, of which few have 
the opportunity of travelling abroad for study, to inform our people at home what the truth of the matter really is.

You are, no doubt, all familiar with Mr.' Haldane's memoranda on the new Territorial Army. These memoranda take the country fully into the Minister's confidence as to the principles underlying the new organisation. You can in this country see for yourself a system which has a very great similarity in point of organisation with the one now introduced in England, and which is an immense step forward on the road to efficiency of tho British Army. But, still, there is one great element lacking-one essential difference between the Swiss system and our own-the principle of the equal obligation resting on every man to serve his own country. It is hoped in England that tho desired results may be attained without the obligation to serve. You will be able to form an opinion to a certain extent after your visit to Switzerland, whether it is possible to do so or not. We believe that the people of England will be satisfied with nothing less than the best. You will be able to tell them how the best can be obtained. It requires courage to tell a people something which is destructive of its most cherished illusions, but, after all, our people do like a man who speaks out, regardless of consequences, and mindful only of his country's good arid the truth. It is little use for the military authorities in England to speak, there is always a suspicion of motive. It is now essentially a matter for the people, and it is the business of those most nearly in touch with the people to inform the people. It is not a party or class matter-it is a national one, and affects us all, rich and poor, 'high and low, simply by virtue of our all being Britons.

Major-General Sir 'Thomas Frıser, K.C.B., C.M.G.-I have heard several lectures on the Swiss Military Militia system, and have read a great deal about it, and with the experience I have thus gained, as well as what I have seen, I congratulate Colonel Delmé-Radcliffe on the admirable lecture he has given us to-day. He is a trained soldier brought up in ono of the best regimental schools of the Regular Army. He knows exactly what to look at, and what to tell us, and ho has been most successful in bringing this subject before us. I am one of those who believe that no nation in these days can ever exist, permanently, unless its men are under the obligation of military service imposed upon everyone alike; and not only that, but under the obligation of receiving such a training and organisation as will fit them to face, at a moment's notice, those enemies who aro well known beforehand, and whoso training is beyond measure -superior to that of the Swiss, of which we have heard to-day. In tho June number of the Fortnightly Review of this year, I have given what I beliere to be the views of Continental authorities on the Swiss Militia. I expected the passing of this Swiss Bill, and accordingly made a few notes on the results which would follow. I will not troulle you with the caralry and artillery, but the infantry will have to do $\mathrm{C5}$ working days' training in the first year and eight working dass' training for each of the remaining seven years. There is a point that you must not lose sight of; when we say that the eight years' service men will have had a certain amount of training, that is not the training of those who are going into war at any particular time. The mean training of an eight years' force is four years. That is evident, because somo may have practically none and others may have eight years. In that period of four years the Swiss Infantry, under the new Bill, which was passed by a majority of 62,000 rotes out of nearly 800,000 voters in the country, get about thirteen weeks of training at the 
time of war, whilst the reservists at the end of eight years' service will have done some eighteen weeks' training. But you must remember that Switzerland is, I think $I$ am right in saying, a State whose autonomy is guaranteed by eight great Powers; therefore switzerland is not at all in the pasition of this country. She is safe in the security of her territory and of her political existence, whatever happens, under the guarantee of theso eight Powers. Sho has only to arm on the principle of limited liability, and what she has to look out for, apparently, is to have arms in the hands of the whole population, so that if a foreign people are tempted to intrude upon her territory, there will be armed nen available against the violence of those foreign soldiers, for the protection of the people, their families, and their property. 'That I think is the object of her army; but that is not the object we havo in view. We shall have to fight if wo have to fight at all, at a moment's notice. We shall be lucky if we get twenty-four hours' notice under the Hague Convention; but war is commenced by telegraph and declared by post, and the P'ost-Office sometimes gous wrong. 'Therefore, at the best ro may get twenty-four hours' notico; at the worst we may' get none. For that reason our position in England is very different from that of Switzerland. A rery curious thing happened a few days ago, as I daresay sou noticed in the papers. In tho Treaty of 1855, wo and France guaranteed the integrity of the then United Fingdom of Norway and Sweden, against Russia only. That Treaty has since been done away with, and four Powers havo now guaranted tho autonomy of Norway. Sweden was invited to be guaranteed, but she declined, and forthwith she raised the amount of first training for her army to one year. If thirteen weeks are sufficient for Switzerland, why should Sweden require one year? The reason is that the set of conditions are totally different; she also can count on the jealousies of Great Powers, but she has to fight for herself without the guarantee that the Powers have given to Norway. I think, therefore, we must look at our position at home under the new Bill, and see how we stand as compared, first with Switzerland, then with Sweden, and then with the groat Powers of Europe. Mr. Haldane has taken immenso pains-greatly to his credit-to try and find out what is going to happen, by going all over the country, and the other day ho expressed a very interesting opinion as to what he thought would be the amount of training that our territorial forco is likely to get. He said, "We calculato that we may hope .... to get 80 per cent. of the territorial army into camp." That means that 60,000 men out of the 300,000 men will not have had any field training at all before war, and that the territorial army is consequently reduced to 240,000 men. Then Mr. Haldane says that a large nucleus of nen will come into the territorial eamps and stay there fifteen days, but he evidently recognises that there will be a very much larger proportion who can only stay a week. That I believe to be absolutely the case throughout the country, so far as I have heard. Then there are the men to whom he referred, as requiring only 15 days every second year; and others as not being able to give a week; and for tho latter he proposes week-end training. I think we may take it, with this territorial army of 240,000 men, we cannot calculate on more than an arerage of a week a year of field training. As the force here is a fouryoar force, the mean period of service will be two years; in two years, therefore, we shall have in the territorial army a mean training of two weeks, in addition to some 50 hours in the drill halls, etc. That will be all the training these men will have before the occurrence of war. I know it is intended that when war comes they shall have six months' training; but I do not think that is a hopo we can take into consideration, at all, in the defence of the country. Therefore, we shall have in this country before war 
comes only a fortnight's training, while the Swiss will have thirteen reeks; the Swedes will have a year at least, and the great military Powers will have at least two years. What passible grounds have we for supposing that fourteen days' training will fit us for war against people who have had two years' training? Or that even if tho Swiss system were applied with a thirteen weeks', or under the proposition Colonel Delmé-Radeliffe has made, eighteen weeks' training, that that would fit our people to face men who have been trained for two years in a most exhaustive way? The arrangements of the Swiss Army may fit the Swiss people very rell indeed under the circumstances of their requirements; but neither thirteen nor eighteen weeks' training will in any way fit the men of this country to face tho best armies that the world has ever seen. It is not possible; it is not common eense. Therefore, while I admire immensely what Switzerland has done, under a system of conscription, including the way in which education is given to the youth of the country, in patriotism, in musletry, in drill, and gymnastics, I submit that people who suppose it does not matter how much or little.a force is trained, are not talking with a knowledge of what war is. In the opinion of the mast experienced soldiers in the country, you cannot teach discipline in the short time in which, it seems, wo are supposed to be able to teach it in this country. Discipline is a slow-growing plant, and it is only acquired after long training. Therefore, I think we camnot daro to say that thirteen weeks or eighteen weeks would fit our territorial army for opposing any great European Powers at a moment's notice. 'There is; among somo, a great desiro in this country to get rid of a regular army, as the force behind law and order which stands in the was of certain aims, and wo should not give it arguments for weakening the efficiency of our regular army. If we could persuade the country that thirteen meeks' (or eighteen reeks') training will enable the territorial forces to beat our foreign enemies, whoever they may be, from across the narrow seas, then it will follow that thirtcen weeks' training and a militia basis of training is quito good enough for the regular army, becauso it will have no more powerful enemies to face throughout the world, either at home or abroad, than the territorial forces will hare to face when war happens. I therefore think the regular army, which is, so far, our only reliable military asset, would be in danger if we were to let the public suppose that we honestly leeliered that thirteen weeks is a. sufficient training for the territorial forces to face enemies composed of the regular armies of other nations in Europe. There is only one other thing I desire to say: If the Swiss army had ever been tried, if it had ever fought under its new formation and conditions in war, then we should know whether it was reliable or not; but I submit that neither history nor experienco has ever shown that an army with a training of thirteen weeks is fit to face armies with a far higher type of training, lasting soveral years.

Colonel J. A. Frroussox (late Rifle Brigade):- To have listened to a rery raluable, interesting and instructive lecture. I think Colonel DelméRadcliffe has done a great patriotic service in giving us this lecture to-day, because it is singularly well timed. My excuse for intervening in the discussion is that for ten years $I$ have never lost an opportunity of urging the absolute necessity, for our national safety, of adopting some srstem like that of the Siriss. May I say also that my late brother, Sir James Fergusson, who served in the Crimea and had a very varied carcer as a Statesman, held that riew mast strongly to the time of his death. Does the country realise that, even if Mr. Haldane's scheme succeeds-and all good citizens and patriotic Britons hope it will succeed-we could not 
mobilise more than 300,000 men, and that they would largely consist, as has been pointed out, of untrained levies; whereas Germany could mobilise in a week threo million highly-trained soldiers. We aro not an island Power : we are a great world-wide Empire. We must think of something beyond the defence of our own shores. Something like the Swiss system I maintain to be absolutely necessary. A hundred years ago Mr. Pitt, as you all know, proposed something rery liko what we adrocato to-day, and what Lord Roberts has done so mich to impress upon the country. He, if you renember in his Act (it was an Act for many years), laid down that every able-bodied citizen betwen the ages of eighteen and thirty must put in four Trainings in the militia. Ho could choose his own time. Of course, that amount of training may not be adequate, but still, it shows that a hundred years ago Mr. Pitt was more far-seeing than our Statesmen of to-day. Is it too much to hope that the King's Ministers will rise to the height of their great obligations?. I do not speak of one Government or of the other. Let them not play the part of Cleons pandering to the ignorant prejudices of tho multitude. The details of the system are unimportant; it is the principle that is important-the principle that every man not incapacitated physically or mentally, is bound, if he be a citizen, to qualify himself to take his share in the defence of the country. That is the principle. If that principle were recognised and adopted, the manhood of the country would gain enormously. We hear much of the deterioration of the race, and a man must be blind indeed who doos not see that the race is deteriorating. If some such system as this was adopted we should have not militarism, but peace; peace with-honour, and immunity from attack.

The Cuninuan (Field-Marshal Earl Roberts):-Colonel DelméRadcliffe has given us a most interesting, and, I think I maj' add, on behalf of all present, a most instructive lecture. My only regret is that so few people have been ablo to hear him. I trust, howerer, that his lecture will be very fully reported, and that all he has told us about the Swiss army will bo very genorally read in this country. As Colonel Delmé-Radeliffe has explained, Switzerland is essentially a "Nation in Arms." Every man considers it not only a sacred duty to render himself an efficient soldier should his services ever bo needed for the defence of his country, but a great privilege to belong to the citizen arny. In fact, in Switzerland the army is part of the national life. Every able-bodied man either belongs, or has belonged, to it, while those who are physically unfitted to bear arms, or unable even to take their place in the non-combatant branches, have, as the lecturer has informed us, to pay in proportion to their means towards tho upkeep of the army. The result of all this is that instead of tho army being looked upon as something with which they have nothing to do, as I deeply regret to think is so generally the case in this country, it is regarded by tho Sriss as their.most valuable asset, not only as a security against invasion, but as the best means of promoting tho commercial, industrial, and educational prosperity of their belored country. The Swiss have long since realised that the habits of discipline which military training inculcates, have made their people better workers, better behaved, and better citizens in every respect, and thes know from bitter experience that, without an efficient army, they would be at the mercy of their moro powerful neighbours rrhenever it suited them to cross the border. They remember what their forefathers told them of the terrible time they went through when their country was inraded in 1792, how the effects of that time were felt during many subsequent years, and the number of saluable lives that wero lost from 
negiecting to take the most ordinary precautions; and they are determined, as far as it is in their power to prevent it, that such a calamity shall never occur again. lt is impassible for me to say how earnestly I wish that our fellow countrymen would take warning by, and follow the example of, the Swiss. But, as a consequence of trouble nover having been brought near their lomes, they know nothing of the horrors of war. For many hundreds of years their battles have been fought on foreign soil, and mainly by the aid of allies and mercenary troops, and they refuso to belicve that these islands can orer be succossfully invaded. They flatter themselves that tho Navy can do ererything that is neededdefend these shores, destroy the enemies' fleots, and protect their commerce. Our Nary may most assuredly be depended upon to do all that a navs can do, but, unless I am very much mistaken, the sailors upon whose skill, courage and intelligence the successful carrying out of these all-important duties wouid depend, woula be the first to tell us that to enable them to destroy the enemies' fleets and protect our commerce, it is essential that their ehips should not be tied to these coasts. We must always remember that however strong, however powerful our Navy may be, circumstances may arise-orer which the sailors may have no control-to prevent our fleets being on tho spot at tho critical moment. In order, therefore, to render these islands absolutely safe, we must have, in addition to the Nary, a sufficient, efficient, and properly organised land force. I am glad to think that the framework of such a force is now being formed by the Secretary of State for War. The right honourable gentleman's schemo is clearly on the right lines, co far as the County Associations are concerned; for whether a citizen army is established on a voluntary or a compulsory system, it must be based on a territorial organisation. But what we members of the National Serrice Icague cannot believe is that tho arny wo require can over be created unless all classes, high and low, rich and poor, men and women, take a practical interest in it, and feel that it belongs to them and that they belong to it in some form or other. It is this feeling, this true patriotic feeling, which has made the Swiss Army what it is to-day, and what Colonel Delmé-Radeliffe has described to us, a national army in every sense of the word, in which every man considers it the greatest honour to serve, while all those who neglect this duty are looked down upon by the Swiss women as inworthy of their country. You will, I am sure, agree with me that we are greatly obliged to Colonel Delmé-Radeliffe for his admirable lecture. $H$ is account of the Swiss Army is mast attractire, and I trust that in time our citizen army will bo similarly organised-so far as it is possible to be under the different conditions of our life-and with regard to the fact that, in addition to a citizen arms, wo aro obliged to maintain a regular army for orersea eervice. I am sure, whether the vote of thanks is proposed by one who does not beliere that a voluntary system will produce an efficient or sufficient army, or is seconded by ono who thinks that a voluntary system will givo us the best army we can possibly have, jou will all agree with me in returning your thanks to Colonel Delmé-Radeliffe for his most admirable lecture.

Lieut.-Colonel J. E. 13. SEEJ, D.S.O., M.P.:-With your permission, and at your suggestion, my lord, I should like to eccond the rote of thanks to Colonel Delmé-Radeliffo for his paper. It were a dull meeting where everybody was of ono mind, but we are all of one mind in thanking Colonel Delme-Radcliffe for his lecture. I should think $I$ am almost the onls man in this room who wholly differs from the view that the glory of the Swiss system is compulsion. I admire the Swiss system, but I believe 
that if you could get tho samo result without compulsion it were far better. And for that reason, perhaps, one who does not agree with the majority may voice the opinion of the minority in joining in thanking Colonel Delmé-Radeliffe for his lecture. In one word, may I say why I strongly believe in the military adrantages of a roluntary system? 'The problem of modern war, not ancient war, not the wars of the days of Pitt, but tho wars of the present day, is the elimination of the unwilling soldier. You may talie a horse to the water, but you cannot make him drink; yon may take the soldiers to the war, but you cannot make them fight, when the long range of modern weapons and tho dispersion of commands renders each man a unit of his own. That is not theory only; wo found it in practice in the war in South Africa, and it was found also even during the war of 1870 between France and Germany. Tho surrender of largo bodies of troops after sustaining quite a small number of casualties is the outstanding foature of modern wars, as everyone who has studied them scientifically has seen to be tho caso. Therefore, if tho object is to eliminate the unwilling, there is a : ast deal to be said for eliminating the unwilling from the start by relying upon roluntary enlistment, as you would do under Mr. Haldane's scheme. Supposing we adopted the Swiss system here with compulsion, I gather from the lecturer that wo should got about 130,000 recruits a year. I gather from $\mathrm{Mr}$. Shce (and I think Lord Roberts is of the samo opinion) that the number would bo rather largerabont 140,000 recruits a year. If, on tho other hand, you adopt a roluntary system, we havo reason to beliove, looking at the past, that we will get about 100,000 recruits a year. Tho question we havo to ask ourselves, as practical men, clearing our minds of shibboleths, is : Which would you sooner have in the hard stross of modern war, when the guns begin to shoot-would you sooner havo a hundred willing men who have been through, let us say, ten weeks' training, or 140 men, forty of whom are unwilling, and have been forced into the service, who have had four weeks' more training? I appeal to every soldier who has ceen a shot fired in action as to which of those two bodies he rould have; I know everyone will say ho wopld sooner have the 100 men, everyone of whom was willing. If that be so, what is our duty? I quite agree with ereryone in this room that it is the duty of every man to serve, and that we ought to endearour to make orery Englishman beliero that it is his duty to serve; but I do not believe in compelling the unwilling. I admire the Swiss army, and owing to tho courtesy of your lecturer a year ago I had the opportunity of secing it at work. Compulsory sorrico may bo suited to that counitry, where they haro no Blue-water School and no Martinet School, both of which have distinguished representatives here to-day. Both of these schools, for different reasons, regard the creation of a homo army with a fow weels' preliminary. training as a useless waste of money and effort. Therefore, while the Swiss have adopted universal service because the Swiss people are all of one mind, I firmly believe that in England, where we have a Blue-water Scliool and where we have a Martinet School, our people, although the most patriotic in the world, havo their patriotic energies sapped by these two schools of thought. I belicve our best plan is to back up with all our heart and strength tho voluntary system commended to us by $\mathrm{Mr}$. Haldane, and commended to us, especially with regard to. its roluntary principles, by His Majesty the King. Therefore, with respect, I would submit that the duty before us is summed up in four words, " Persuade all, compel none"; and in that spirit I most heartily second the rote of thanks.

Admiral Sir Natnasiel Bowbex-Syiti, K.C.B.:--Beforo we separate, $\therefore$ I should like to propose that we accord a hearty rote of thanks to our dis- 
tinguished Chairman, Lord Roberts, for taking the chair this afternoon. Not only this company to-day, but a large and growing number of his fellow-countrymen, heartily thank his lordship for the splendid efforts he is making to establish a system of national training. Let me just say a word with regard to the Blue-water School, which has been referred to by one of the speakers. I want you to understand that there are a rery large number of sailors who are entirely with his lordship in the appeal he is now making. Whilst agreeing that the Navy'must be our first consideration, they know perfectly well that the Nay has its limitations; and to show, you that this is the case, I may tell you that today thero aro amongst the members of the National Service League thirty admirals. It is unfortunately the case that men belonging to, what I may call the extremo Blue-water School, oceasionally write letters to the Press which causes thd man in the street to come to the conclusion that we want no land forces so long as our Navy is kept. supreme, but however clever such letters may be, the general public should understand that the writers aro only expressing their omn viems, and not those of their brother officers. If the British Limpire is to be maintained in its integrity we know that, in addition to a porrerful Navy, and a sufficient Army, we should have a largo trained reservo to maintain us in, peace and. to meet any future emergencies. 